\title{
Analysis of Multi-Residue Pesticides in Vegetable Samples Using Solid-Phase Micro-Extraction (SPME) Coupled to Gas Chromatography-Electron-Capture Detector (GC-ECD)
}

\author{
Prashant Chaturvedi ${ }^{1}$, Rupender Kumari ${ }^{2}$, Rakesh Roshan $\mathrm{Jha}^{1}$ and Devendra Kumar Patel ${ }^{*}$ \\ ${ }^{1}$ Analytical Chemistry Laboratory, Regulatory Toxicology Group, Analytical Chemistry Laboratory \& Regulatory Toxicology Group, CSIR-Indi- \\ an Institute of Toxicology Research, Vishvigyan Bhawan, 31, M. G. Marg, Lucknow, Uttar Pradesh, India \\ ${ }^{2}$ Toxicology Division, Central Forensic Science Laboratory, Kolkata, West Bengal, India
}

*Corresponding author: Dr. Devendra Kumar Patel, Analytical Chemistry Laboratory \& Regulatory Toxicology Group, CSIR-Indian Institute of Toxicology Research, Vishvigyan Bhawan, 31, M. G. Marg, Lucknow - 226001, Uttar Pradesh, India, Tel: + 91522-2627586-ext-228/ Fax: 91-522-2628227; E-mail: dkpatel@iitr.res.in

\begin{abstract}
A fast, simple, solventless and inexpensive sample preparation method based on Head space solid-phase microextraction (HS-SPME) coupled to gas chromatography-electron-capture detector (GC-ECD) is proposed for the determination of mix pesticide residues from vegetable samples. Polydimethylsiloxane (PDMS, $100 \mu \mathrm{m}$ ) fiber was used in this study. The mix pesticides (24 nos.) including organochlorines (15), organophosphates (06) and synthetic pyrethriods (03) were analysed in the vegetable samples (Cabbage, Tomato, Cauliflower, Chilli, Okra, Brinjal, Bottle gourd, Cucumber, Beetroot, Spinach, and Radish) collected from in and around of Lucknow city, India. Present study revealed the presence of HCH, DDT, methylparathion, malathion, chlorpyrifos, monocrotophos, endosulfan, cypermethrin, fenvalerate pesticides. Pesticides residue levels were compared with MRL fixed by Prevention of Food Adulteration Act (PFA), Govt. of India 1954. The method detection limits were in a linearity range of $0.003-0.24 \mathrm{mg} / \mathrm{kg}$. A recovery percent varies from 86.1 to $96.4 \% \mathrm{with}$ relative standard deviation (RSD) from 7.8 to $13.8 \%$. The outcomes of the present study point towards the crucial need of implementing strict food safety standards in order to put check on these kinds of health hazardous food contamination.
\end{abstract}

Keywords: HS-SPME; Pesticides; Vegetable; GC-ECD

\section{Introduction}

Vegetables are important for the maintenance of health. They provide vitamins, antioxidants, enzymes, minerals and fiber. Daily consumption of at least 200-300 grams of fruits and 250 grams of vegetables is recommended for all age groups. India is the second largest user of pesticides in Asia. However, pesticide consumption in India is relatively low i.e. $0.33 \mathrm{~kg}$ / hectare. When compared to the pesticide consumption of $3.07 \mathrm{~kg}$ /hectare in France, $4.17 \mathrm{~kg} /$ hectare in Italy and $13.1 \mathrm{~kg} /$ hectare in Japan and more than $15 \mathrm{~kg}$ / hectare in United Kingdom, Canada and United States (Associated Chambers of Commerce and Industry of India (ASSOCHAM). According to Indian Pesticide Report it is estimated that India loses approximately $18 \%$ of its crop yield anually worth Rs.900 billion due to pest attack. As a result, farmers began to rely on using more and more pesticides to protect crops from pests, weeds, rats, mice, flies and other insects from consuming and contaminating crops in agricultural field as well as for protecting fruits, vegetables, legumes and cereals etc. when they are being stored. Many researchers have reported the residues of OCs, OPs and pyrethroids, along with fungicide and herbicides
Received date: July 13, 2018 Accepted date: October 17, 2018 Published date: October 24, 2018

Citation: Patel, D.K., et al. Analysis of Multi-Residue Pesticides in Vegetable Samples Using Solid-Phase Micro-Extraction (SPME) Coupled to Gas Chromatography-Electron-Capture Detector (GC-ECD). (2018) J Analytic Bioanalytic Tech 3(1): 7- 13.

Copyright: (C) 2018 Patel, D.K. This is an Open access article distributed under the terms of Creative Commons Attribution 4.0 International License. 
Citation: Patel, D.K., et al. Analysis of Multi-Residue Pesticides in Vegetable Samples Using Solid-Phase Micro-Extraction (SPME) Coupled to Gas Chromatography-Electron-Capture Detector (GC-ECD). (2018) J Analytic Bioanalytic Tech 3(1): 7- 13.

in fruit and vegetables of indian origin ${ }^{[1-13]}$.

Several methodologies have been developed for sample preparation prior to the analysis of pesticides from biological, food or environmental samples ${ }^{[14,15]}$. SPME was first developed in 1989 by Pawliszyn and coworkers and has been marketed by Supelco since 1993. Subsequently, the technique has grown enormously ${ }^{[16-18]}$. This technique integrates sampling, extraction, pre concentration and sample introduction in a simple single step procedure. Although SPME was initially introduced for the extraction of organic compounds from water samples ${ }^{[19]}$, but, soon after, SPME have been successfully applied for the determination of pesticides in various complex sample matrices ${ }^{[20-28]}$. Application of SPME was described by many researchers for the determination of pesticide residues determination in fruits or for the determination of volatile organic compounds in food commodities. SPME is the advanced micro extraction technique that is being increasingly used in the isolation and extraction of organic contaminants from environmental/food/biological samples. In this study, an easy and solventless SPME method has been developed and validated followed by GC-ECD analysis for the simultaneous determination of multi-residue pesticides (24 Nos.) from raw vegetable samples.

\section{Materials and Methods}

\section{Chemicals and Reagents}

In the present study 15 organochlorine pesticides $(\alpha-\mathrm{HCH}$, $\beta-\mathrm{HCH}, \gamma-\mathrm{HCH}, \delta-\mathrm{HCH}$, aldrin, diedrin, endrin, Alachlor, $\alpha$-endosulfan, $\beta$-endosulfan, endosulfan sulfate, 4,4-DDE, 4,4-DDD, 2,4-DDT, 4,4-DDT) 06 organophosphate pesticides (Phorate , Monocrotophos, Methylparathion, Malathion Chlorpyrifos and Ethion) and 03 Pyethyroids (cypermethrin, fenvalerate and deltamethrin) were analysed. The individual pesticide standards $>$ 99\% pure were procured from Sigma Aldrich (Bellefonte, PA, USA) and n-hexane (HPLC grade) was procured from Merck, India. Stock standard solutions of individual compound of concentrations between 100 and $850 \mu \mathrm{g} / \mathrm{ml}$ were prepared in n-hexane. The mixed standard solution of $2.0 \mathrm{ng} / \mathrm{ml}$ concentration of each compound was prepared by serial dilution of the stock solutions with n-hexane. To avoid pesticide degradation the working standard solution was freshly prepared every week and stored at $4^{\circ} \mathrm{C}$ during the study. SPME holder, $1 \mathrm{~cm}$ long polydimethylsiloxane fiber (PDMS $100 \mu \mathrm{m}$ ), sampling stand, stirring hot plate, $4 \mathrm{ml}$ amber glass vials (O.D. $15 \mathrm{~mm} \times \mathrm{H} 45 \mathrm{~mm}$ ) with PTFE/Silicone septa and magnetic stirring flea were obtained from Sigma Aldrich (Bellefonte, PA, USA).

\section{Instrumentation}

Perkin Elmer Clarus 500 Gas chromatograph equipped with $\mathrm{Ni}^{63}$ electron capture detector (GC-ECD) was used with a split less injector $(0.75 \mathrm{~mm}$ I.D. glass liner, split less time) for thermal desorption. All the separations were carried out on Elite - 5 (30 $\mathrm{m}$ X $0.25 \mathrm{~mm}, 0.25 \mu \mathrm{m}$ ) capillary column (Perkin Elmer). The oven temperature was started at $200^{\circ} \mathrm{C}$ with $2 \mathrm{~min}$ hold and then increased to $280^{\circ} \mathrm{C}$ at a rate of $2^{\circ} \mathrm{C} / \mathrm{min}$. The fiber depth in the injector was set to $2.5 \mathrm{~cm}$ and the thermal desorption time in the split less injector was $10 \mathrm{~min}$ at $280^{\circ} \mathrm{C}$. The temperatures of injector port and detector were set at $280^{\circ} \mathrm{C}$ and $350^{\circ} \mathrm{C}$, respectively. Ultrapure Nitrogen (99.999\%) was used as carrier gas with a flow rate of $0.79 \mathrm{ml} / \mathrm{min}$.

\section{Sample collection site}

Total 110 (10 samples of each variety) vegetable samples of Cabbage, Tomato, Cauliflower, Chilli, Okra, Brinjal, Bottle gourd, Cucumber, Beetroot, Spinach and Radish were collected from different market locations within Lucknow city, India $\left(26^{\circ} 55^{\prime} \mathrm{N}\right.$, $80^{\circ} 59^{\prime} \mathrm{E}$ ) in September-October 2011. Samples were procured and kept in refrigerator and analyzed next day of the collection.

\section{SPME procedure}

$10 \mathrm{gm}$ of vegetable sample was homogenized with $10 \mathrm{ml}$ of Milli-Q (Millipore, Milford, MA, USA) water using a high speed blender. Further $2.0 \mathrm{ml}$ of homogenate, $0.6 \mathrm{~g}$ of $\mathrm{NaCl}$ and magnetic flea were added in $4.0 \mathrm{ml}$ amber glass vial capped with PTFE-faced silicon septa. PDMS $(100 \mu \mathrm{m})$ fiber was then exposed in glass vial in headspace for $20 \mathrm{~min}$ at $80^{\circ} \mathrm{C}$. At stirring speed $400 \mathrm{rpm}$. After adsorption the syringe was removed from the vial and thermal desorption of the analytes was carried out by inserting the fiber into the $\mathrm{GC}$ injection port (at $280^{\circ} \mathrm{C}$ ) for 10 minutes. Magnetic fleas were cleaned with detergent and water and finally rinsed with acetone for next set of SPME extraction.

The values of linearity range, coefficients of determination $\left(r^{2}\right)$ limit of detection (LOD), and limit of quantification (LOQ) corresponding to individual pesticide have been depicted in Table 1.

Recovery study was conducted by performing HSSPME on the homogenate vegetable sample being spiked with mix pesticide standard solution at five-level concentrations as depicted in Table 1. Three replicate samples were used at each concentration. Control samples were processed along with spiked ones. GC-ECD chromatogram of targeted analytes recovered using HS-SPME from homogenate vegetable sample being spiked with mix pesticides standard solution at $0.02 \mathrm{mg} /$ $\mathrm{kg}$ as shown in Fig.1. Recovery percentages corresponding to each targeted analytes were found in the range of 86.1 - 96.4 and linearity curve with $\mathrm{R}^{2}$ ranging between 0.9847 and 0.9986 . were also depicted in Table 1.

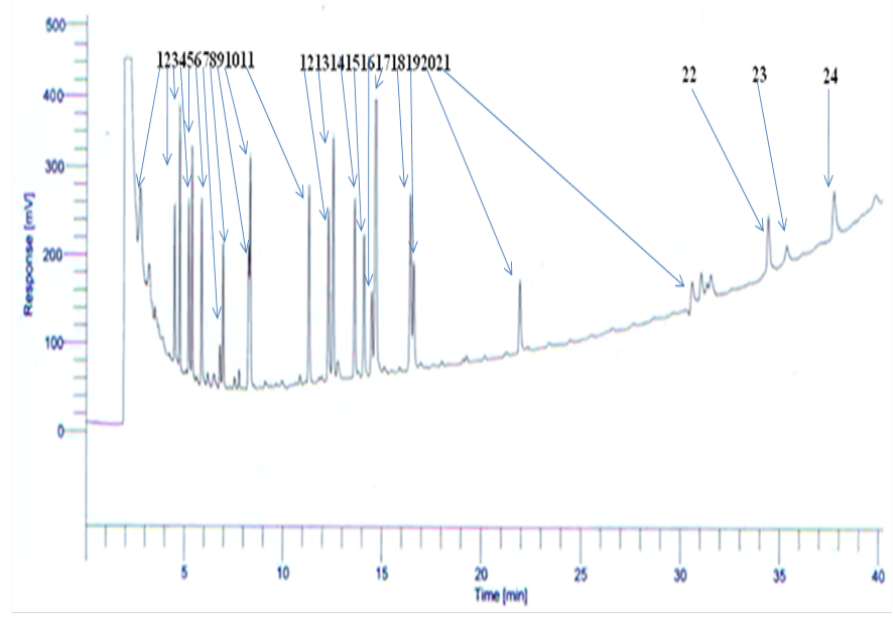

Figure 1: GC-ECD chromatogram of HS-SPME recovered analytes from a homogenate vegetable sample being spiked $(0.002 \mathrm{mg} / \mathrm{kg})$ with a mix standard solution of selected pesticides i.e. (1) Phorate, (2) $\alpha-\mathrm{HCH}$, (3) $\beta-\mathrm{HCH}$, (4) $\gamma-\mathrm{HCH}$, (5) $\delta-\mathrm{HCH}$ (6) Methylparathion, (7) Malathion, (8) Monochrotophos, (9) Alachlor, (10) Chlorpyrifos, (11) Aldrin, (12) $\alpha$-Endosulfan, (13) 4,4, DDE, (14) Dieldrin, (15) Endrin, (16) $\beta$-Endosulfan, (17) 4,4 DDD, (18) Ethion, (19) 2,4 DDT, (20) En- 
dosulfan Sulfate, (21) 4,4 DDT, (22) Cypermethrin, (23) Fenvalerate, (24) Deltamethrin

Table 1: Performance evaluation of different pesticides in vegetable analyzed with HS-SPME-GC-ECD

\begin{tabular}{|c|c|c|c|c|c|c|}
\hline Compound & $\begin{array}{l}\text { Range (mg/ } \\
\mathrm{kg})\end{array}$ & $\mathrm{R}^{2}$ & $\begin{array}{l}\text { RSD } \\
(\%)\end{array}$ & $\begin{array}{l}\text { LOD } \\
(\mathrm{mg} / \\
\mathrm{kg})\end{array}$ & $\begin{array}{l}\mathrm{L} \text { O Q } \\
(\mathrm{m} \mathrm{g} / \\
\mathrm{kg})\end{array}$ & $\begin{array}{l}\mathrm{R} \text { e } \\
\text { covery } \\
(\%)\end{array}$ \\
\hline$\alpha-\mathrm{HCH}$ & $0.006-0.096$ & 0.9890 & 11.5 & 0.002 & 0.006 & 94.2 \\
\hline$\beta-\mathrm{HCH}$ & $0.006-0.096$ & 0.9986 & 8.7 & 0.002 & 0.006 & 86.1 \\
\hline$\gamma-\mathrm{HCH}$ & 0.006-0.096 & 0.9792 & 6.4 & 0.002 & 0.006 & 93.8 \\
\hline d- $\mathrm{HCH}$ & $0.006-0.096$ & 0.9890 & 9.2 & 0.002 & 0.006 & 96.4 \\
\hline Aldrin & $0.003-0.048$ & 0.9892 & 8.4 & 0.001 & 0.003 & 88.9 \\
\hline $\begin{array}{l}\alpha \text {-Endosul- } \\
\text { fan }\end{array}$ & $0.015-0.240$ & 0.9987 & 10.8 & 0.005 & 0.015 & 90.1 \\
\hline Dieldrin & $0.006-0.096$ & 0.9992 & 8.5 & 0.002 & 0.006 & 94.5 \\
\hline Alachlor & $0.006-0.096$ & 0.9985 & 12.8 & 0.002 & 0.006 & 89.4 \\
\hline 4,4'-DDE & $0.006-0.096$ & 0.9943 & 9.7 & 0.002 & 0.006 & 88.9 \\
\hline Endrin & 0.006-0.096 & 0.9890 & 10.1 & 0.002 & 0.006 & 91.7 \\
\hline $\begin{array}{l}\beta \text {-Endosul- } \\
\text { fan }\end{array}$ & $0.015-0.240$ & 0.9797 & 11.9 & 0.005 & 0.015 & 88.2 \\
\hline 4,4'-DDD & $0.006-0.096$ & 0.9980 & 8.1 & 0.002 & 0.006 & 89.4 \\
\hline 2-4'-DDT & $0.006-0.096$ & 0.9981 & 7.8 & 0.002 & 0.006 & 87.1 \\
\hline $\begin{array}{l}\text { Endosulfan } \\
\text { Sulfate }\end{array}$ & $0.015-0.240$ & 0.9847 & 9.6 & 0.005 & 0.015 & 90.9 \\
\hline 4,4'-DDT & 0.006-0.096 & 0.9915 & 10.6 & 0.002 & 0.006 & 93.7 \\
\hline Phorate & $0.006-0.096$ & 0.9948 & 9.7 & 0.002 & 0.006 & 94.9 \\
\hline $\begin{array}{l}\text { Met h y l- } \\
\text { parathion }\end{array}$ & $0.006-0.096$ & 0.9962 & 9.4 & 0.002 & 0.006 & 89.1 \\
\hline Malathion & $0.015-0.240$ & 0.9986 & 8.5 & 0.005 & 0.015 & 91.8 \\
\hline $\begin{array}{l}\text { Chlorpyr- } \\
\text { ifos }\end{array}$ & $0.003-0.048$ & 0.9978 & 10.3 & 0.001 & 0.003 & 88.6 \\
\hline $\begin{array}{l}\text { Monocro- } \\
\text { tophos }\end{array}$ & $0.006-0.096$ & 0.9991 & 13.8 & 0.002 & 0.006 & 87.2 \\
\hline Ethion & $0.006-0.096$ & 0.9928 & 11.4 & 0.002 & 0.006 & 93.7 \\
\hline $\begin{array}{l}\text { Cyperme- } \\
\text { thrin }\end{array}$ & $0.015-0.240$ & 0.9980 & 9.4 & 0.005 & 0.015 & 90.9 \\
\hline Fenvalerate & $0.015-0.240$ & 0.9983 & 8.6 & 0.005 & 0.015 & 89.4 \\
\hline $\begin{array}{l}\text { Deltame- } \\
\text { thrin }\end{array}$ & $0.015-0.240$ & 0.9919 & 8.1 & 0.005 & 0.015 & 91.1 \\
\hline
\end{tabular}

\section{Optimization of extraction conditions}

Different parameters influencing HS-SPME were optimized such as extraction temperature, extraction time, sodium chloride amounts, desorption temperature, desorption time of the fiber in the GC injector port. All the conditions of SPME coupled to GC-ECD were systematically optimized using such an approach that the finally optimized conditions could support reasonable extraction of all the analytes of dissimilar volatilities.

In order to study the temperature effect on extraction of targeted analytes from spiked vegetable sample, HS-SPME was performed at $60,70,80$ and $90^{\circ} \mathrm{C}$ and the peak areas of target analytes were observed. Maximum area of analytes was achieved at $80^{\circ} \mathrm{C}$ because when the sample temperature is increased, the vapor pressure of the analyte and consequently the concentration of analyte in the headspace were increased. From a kinetic view, higher temperatures increase the transfer rate of the analytes from the matrix (e.g. water) towards the headspace, while thermodynamically higher temperatures decrease the analytes partition coefficients between the headspace and SPME fiber. Peak areas were decreased when temperature exceeded $80^{\circ} \mathrm{C}$ because adsorption is an exothermic process and disfavored at high temperature therefore $80^{\circ} \mathrm{C}$ was selected as working temperature for the analysis. (Figure 2)

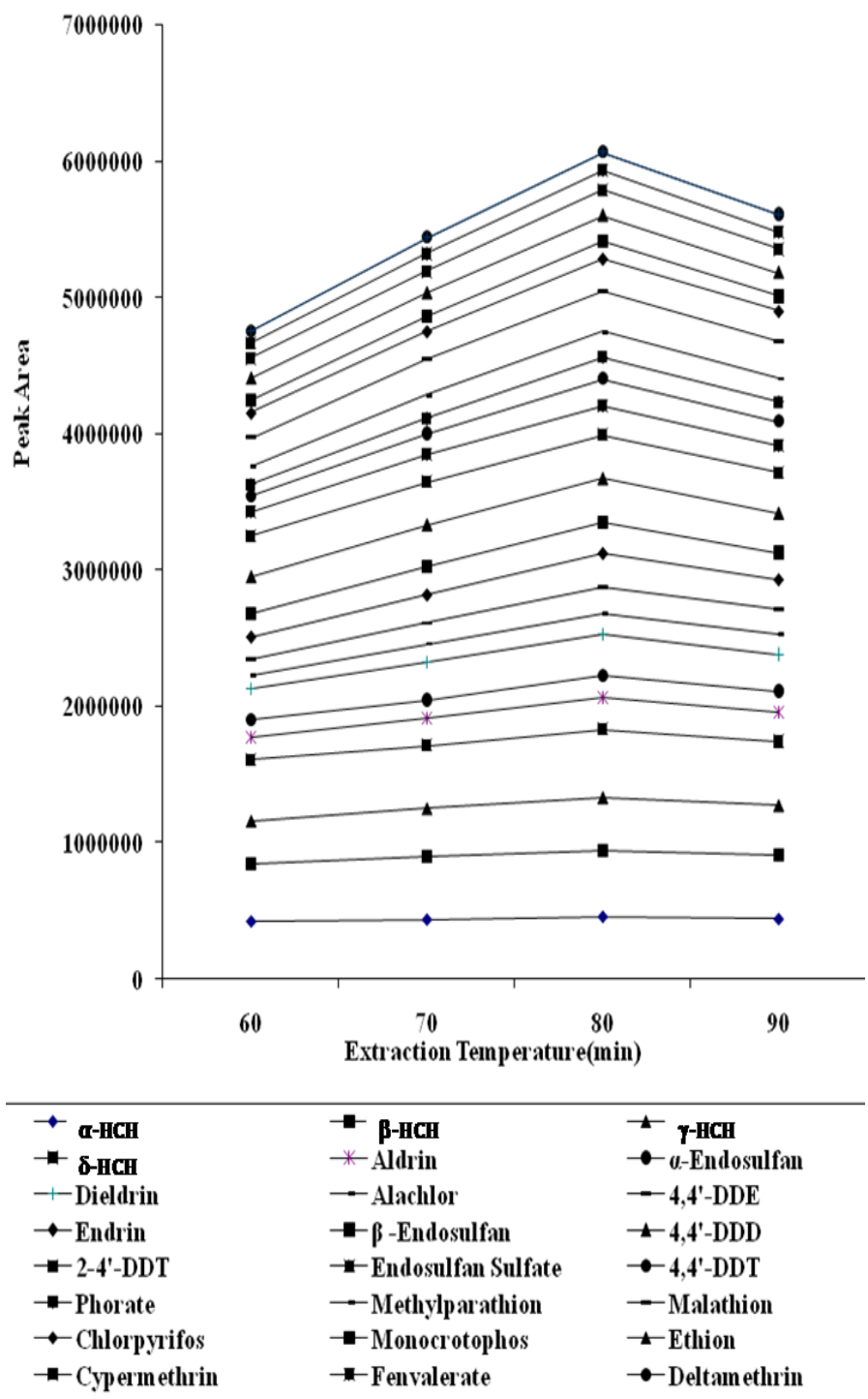

Figure 2: Effect of extraction temperature on the peak areas of targeted analytes

Effect of change in extraction time was observed aby performing HS-SPME at $80^{\circ} \mathrm{C}$ for $05,10,20$ and 40 minutes. Maximum peak areas were observed when the extraction time was 20 mins. (Figure 3) 
Citation: Patel, D.K., et al. Analysis of Multi-Residue Pesticides in Vegetable Samples Using Solid-Phase Micro-Extraction (SPME) Coupled to Gas Chromatography-Electron-Capture Detector (GC-ECD). (2018) J Analytic Bioanalytic Tech 3(1): 7- 13.

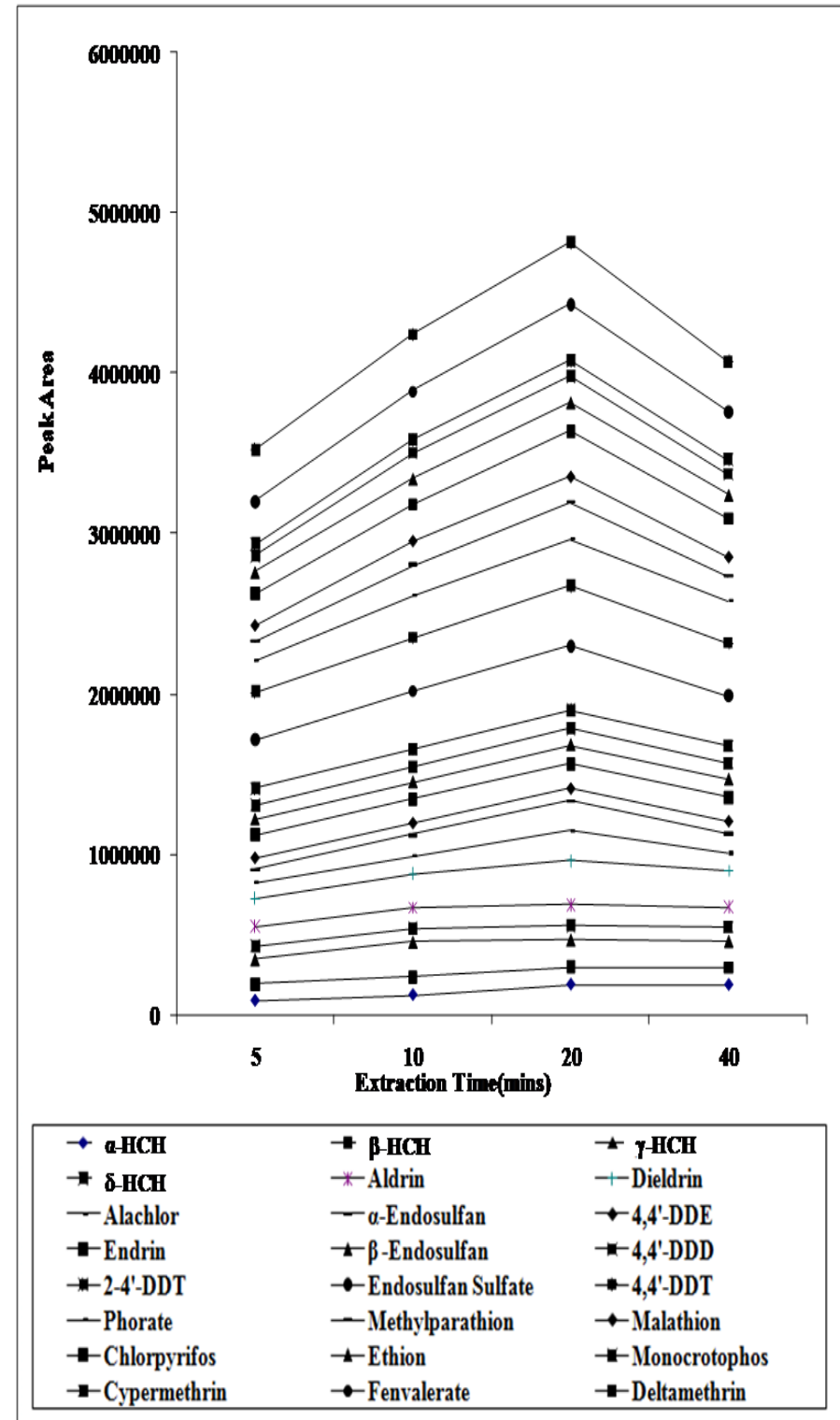

Figure 3: Effect of extraction time on the peak areas of targeted analytes

Spiked vegetable sample were treated with $\mathrm{NaCl}(\mathrm{w} / \mathrm{v})$ $0,10,20,30,40 \%$. The $30 \%(\mathrm{w} / \mathrm{v}) \mathrm{NaCl}$ concentration was selected for extraction because peak areas of pesticides were declined when more than $30 \% \mathrm{NaCl}(\mathrm{w} / \mathrm{v})$ was added. Addition of sodium chloride reduced the solubility of target compounds in water by increasing distribution of analytes in the headspace and onto the SPME fiber. The presence of higher concentrations of sodium chloride within the matrix may reduce the molecular movement of targeted analytes, resulting in decrease in extraction efficiency because excess concentration of $\mathrm{NaCl}$ deposited on SPME fiber. (Figure 4)

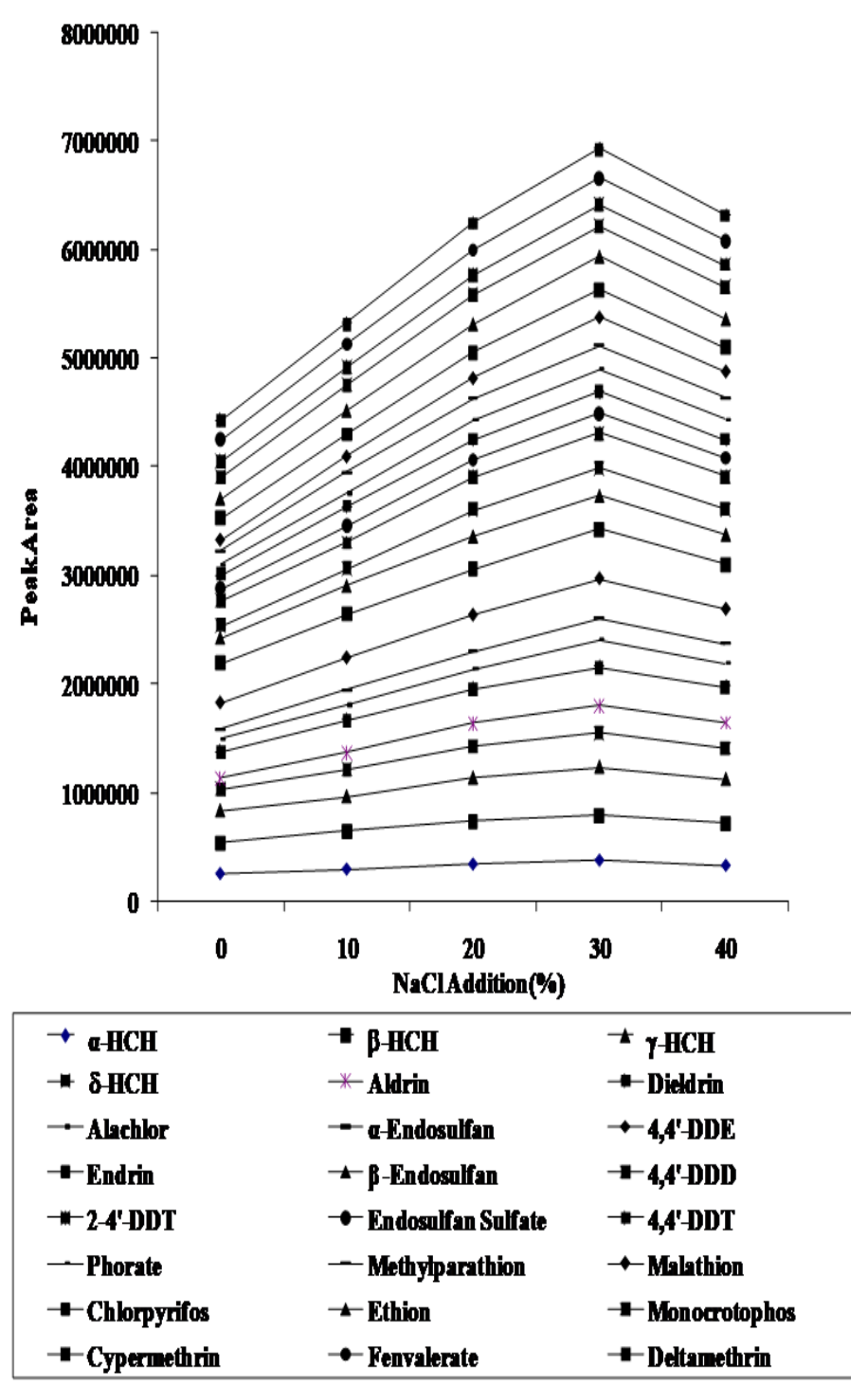

Figure 4: Effect of salt addition $(\mathrm{NaCl})$ on the peak areas of targeted analytes

\section{Recovery of Proposed Method}

To evaluate extraction recoveries, extractions were performed in triplicates on spiked vegetable sample at finally optimized extraction conditions Recoveries were found in the range of $86.1-96.4 \%$ as shown in Table 1 .

\section{Result and Discussion}

Residues of HCH, DDT, methylparathion, malathion, chlorpyrifos, monocrotophos, endosulfan, cypermethrin, fenvalerate pesticides were detected in vegetable samples (Table 2) 
Table 2: Pesticide residues concentration in vegetable collected from different areas of Lucknow City

\begin{tabular}{|c|c|c|c|c|}
\hline Vegetable & $\begin{array}{l}\text { Samples } \\
\text { Analysed }\end{array}$ & Pesticide & $\begin{array}{c}\text { MRL } \\
(\mathrm{mg} / \mathrm{kg}) \\
(\mathrm{PFA})\end{array}$ & $\begin{array}{l}\text { Mean Res- } \\
\text { idue level } \\
(\mathrm{mg} / \mathrm{kg})\end{array}$ \\
\hline \multirow{7}{*}{ Tomato } & 10 & $\gamma-\mathrm{HCH}$ & 1.0 & 0.37 \\
\hline & 10 & $\sum \mathrm{DDT}$ & 3.5 & 0.51 \\
\hline & 10 & Malathion & 3.0 & 0.46 \\
\hline & 10 & Chlorpyrifos & 0.2 & 0.28 \\
\hline & 10 & Endosulfan & 2.0 & 0.49 \\
\hline & 10 & Fenvalerate & 2.0 & 0.82 \\
\hline & 10 & Cypermethrin & 0.2 & 0.12 \\
\hline \multirow{7}{*}{ Cabbage } & 10 & $\sum \mathrm{DDT}$ & 3.5 & 0.50 \\
\hline & 10 & Methyl parathion & 1.0 & 0.79 \\
\hline & 10 & Malathion & 3.0 & 0.62 \\
\hline & 10 & Chlorpyrifos & 0.01 & 0.01 \\
\hline & 10 & Endosulfan & 2.0 & 0.40 \\
\hline & 10 & Cypermethrin & 2.0 & 0.28 \\
\hline & 10 & Fenvalerate & 2.0 & 1.08 \\
\hline \multirow{6}{*}{$\begin{array}{l}\text { Cauliflow- } \\
\text { er }\end{array}$} & 10 & $\sum \mathrm{DDT}$ & 3.5 & 0.38 \\
\hline & 10 & Methyl parathion & 1.0 & 0.85 \\
\hline & 10 & Malathion & 3.0 & 0.88 \\
\hline & 10 & Chlorpyrifos & 0.01 & 0.01 \\
\hline & 10 & Endosulfan & 2.0 & 0.32 \\
\hline & 10 & Fenvalerate & 2.0 & 0.55 \\
\hline \multirow{5}{*}{ Chilli } & 10 & $\gamma-\mathrm{HCH}$ & 1.0 & 0.22 \\
\hline & 10 & Methyl parathion & 1.0 & 0.55 \\
\hline & 10 & Malathion & 3.0 & 0.57 \\
\hline & 10 & Chlorpyrifos & 0.2 & 0.12 \\
\hline & 10 & Endosulfan & 2.0 & 0.51 \\
\hline \multirow{6}{*}{ Okra } & 10 & $\sum \mathrm{DDT}$ & 3.5 & 0.35 \\
\hline & 10 & Methyl parathion & 1.0 & 0.21 \\
\hline & 10 & Malathion & 3.0 & 0.52 \\
\hline & 10 & Chlorpyrifos & 0.2 & 0.36 \\
\hline & 10 & Endosulfan & 2.0 & 0.29 \\
\hline & 10 & Cypermethrin & 0.2 & 0.08 \\
\hline \multirow{5}{*}{ Brinjal } & 10 & $\gamma-\mathrm{HCH}$ & 1.0 & 0.11 \\
\hline & 10 & Malathion & 3.0 & 0.41 \\
\hline & 10 & Endosulfan & 2.0 & 0.38 \\
\hline & 10 & Cypermethrin & 0.2 & 0.26 \\
\hline & 10 & Fenvalerate & 2.0 & 0.31 \\
\hline \multirow{6}{*}{$\begin{array}{l}\text { Bottle } \\
\text { gourd }\end{array}$} & 10 & $\sum \mathrm{DDT}$ & 3.5 & 0.37 \\
\hline & 10 & Methyl parathion & 1.0 & 0.72 \\
\hline & 10 & Malathion & 3.0 & 2.16 \\
\hline & 10 & Chlorpyrifos & 0.2 & 0.27 \\
\hline & 10 & Endosulfan & 2.0 & 0.34 \\
\hline & 10 & Fenvalerate & 2.0 & 0.91 \\
\hline
\end{tabular}

\begin{tabular}{|c|c|c|c|c|}
\hline \multirow{6}{*}{ Cucumber } & 10 & Methyl parathion & 1.0 & 0.64 \\
\hline & 10 & Malathion & 3.0 & 0.98 \\
\hline & 10 & Chlorpyrifos & 0.2 & 0.21 \\
\hline & 10 & Endosulfan & 2.0 & 0.42 \\
\hline & 10 & Cypermethrin & 0.2 & 0.16 \\
\hline & 10 & Fenvalerate & 0.2 & 0.14 \\
\hline \multirow{5}{*}{ Beetroot } & 10 & Methyl parathion & 1.0 & 0.75 \\
\hline & 10 & Malathion & 3.0 & 2.18 \\
\hline & 10 & Chlorpyrifos & 0.2 & 0.15 \\
\hline & 10 & Endosulfan & 2.0 & 0.57 \\
\hline & 10 & Cypermethrin & 0.2 & 0.15 \\
\hline \multirow{4}{*}{ Spinach } & 10 & Malathion & 3.0 & 2.80 \\
\hline & 10 & Endosulfan & 2.0 & 0.46 \\
\hline & 10 & Cypermethrin & 0.2 & 0.17 \\
\hline & 10 & Fenvalerate & 2.0 & 0.05 \\
\hline \multirow{5}{*}{ Radish } & 10 & Malathion & 3.0 & 2.18 \\
\hline & 10 & Chlorpyrifos & 0.2 & 0.28 \\
\hline & 10 & Endosulfan & 2.0 & 0.53 \\
\hline & 10 & Cypermethrin & 0.2 & 0.24 \\
\hline & 10 & Fenvalerate & 2.0 & 0.19 \\
\hline
\end{tabular}

$\gamma-\mathrm{HCH}$ was detected in 28 out of the 110 samples. The average lower concentration was $0.11 \mathrm{mg} / \mathrm{kg}$ in Brinjal samples while higher mean concentration was $0.37 \mathrm{mg} / \mathrm{kg}$ found in Tomato samples. The residues of $\gamma-\mathrm{HCH}$ were above MRL in 09 samples as per PFA Act.

$\sum$ DDT was detected in 21 out of the 110 samples. The average lower concentration was $0.35 \mathrm{mg} / \mathrm{kg}$ in Okra samples while average higher concentration was $0.51 \mathrm{mg} / \mathrm{kg}$ found in Tomato samples. The residues of $\gamma-\mathrm{HCH}$ were above MRL in 07 samples as per PFA Act.

Methyparathion was detected in 38 out of the 110 samples. The average lower concentration was $0.21 \mathrm{mg} / \mathrm{kg}$ in Okra samples while higher concentration was $0.85 \mathrm{mg} / \mathrm{kg}$ found in Cauliflower samples. The residues of methyparathion were above MRL in 12 samples.

Malathion residues were found in 47 samples out of the 110. Minimum average concentration was found 0.41 in case of Brinjal samples and maximum concentration $0.62 \mathrm{mg} / \mathrm{kg}$ was found in cabbage samples. The residues of Malathion were below maximum residue level.

Chlorpyrifos residues were detected in 49 out of the 110 samples. The average lower concentration was $0.01 \mathrm{mg} / \mathrm{kg}$ in cabbage samples and high $0.153 \mathrm{mg} / \mathrm{kg}$ was found in okra samples. The residues of chlorpyrifos were above MRL in 08 samples.

Total Endosulfan ( $\alpha$-Endosulfan, $\beta$-Endosulfan and Endosulfan sulfate) was found in 64 vegetable samples. Lowest average concentration was $0.29 \mathrm{mg} / \mathrm{kg}$ in Okra samples while highest concentration was $0.57 \mathrm{mg} / \mathrm{kg}$ in Beetroot samples. The residues of Endosulfan were above MRL in 17 samples.

Cypermethrin was detected in 48 out of the 110 samples. The average lower concentration was $0.08 \mathrm{mg} / \mathrm{kg}$ in Okra samples while higher concentration was $0.28 \mathrm{mg} / \mathrm{kg}$ found in 
Citation: Patel, D.K., et al. Analysis of Multi-Residue Pesticides in Vegetable Samples Using Solid-Phase Micro-Extraction (SPME) Coupled to Gas Chromatography-Electron-Capture Detector (GC-ECD). (2018) J Analytic Bioanalytic Tech 3(1): 7- 13.

Cabbage samples. The residues of Cypermethrin were above MRL in 12 samples.

Fenvalerate residues were detected in 39 out of the 110 samples. The average lower concentration was $0.31 \mathrm{mg} / \mathrm{kg}$ in Brinjal samples and high $1.08 \mathrm{mg} / \mathrm{kg}$ was found in Cabbage samples. The residues of Fenvalerate were above MRL in 19 samples as per PFA Act.

\section{Conclusion}

A periodical monitoring of pesticide residues in food items are the recent need of consumers. Thus, in this study, a fast, simple, and solvent free Headspace SPME-GC method has been developed which was successfully applied for the analysis of organochlorine, organophosphate and pyrethroid pesticides in vegetable samples in order to check pesticide contamination in raw vegetables. Instead of employing tiresome conventional extraction procedures which required hazardous organic solvents, lengthy and multiple extractions steps, this method provide an easy, sensitive and single step sample preparation procedure for the simultaneous extraction as well as pre concentration of the 24 nos. of pesticides.

Acknowledgement: The authors wish to thank the Director, Council of Scientific and Industrial Research - Indian Institute of Toxicology Research (CSIR-IITR), Lucknow, India, for providing the necessary facilities for the present study.

Competing interest: The authors do not have any relevant affiliations, financial involvement and conflicts with any organization and person with the subject matter and material discussed in the manuscript. The authors were not influenced by, or may be perceived to be influenced by, any personal or financial relationship with other people or organizations for the interpretation of data or presentation of information depicted in the present study. The author did not get any writing assistance for the production of this manuscript.

Abbreviations: HCH: Hexachlorocyclohexane, $\alpha$ : Alpha, $\boldsymbol{\beta}$ : Beta, $\gamma$ : Gamma, $\delta$ : Delta, DDE: Dichloro Diphenyl dichloroethylene, DDD: Dichloro Diphenyl dichloroethane, DDT: Dichloro Diphenyl trichloroethane, PDMS: Polydimethylsiloxane, OCs: Organochlorines, Ops: Organophosphorus, HS - SPME: Headspace Solid-Phase Micro-Extraction, RPM: Rounds per minute, GC - ECD - Electron-Capture Detector, $\mathrm{Ni}^{63}$ - Nickel63

\section{References}

1. Arthur, C.L., Pawliszyn, J. Solid phase microextraction with thermal desorption using fused silica optical fibers. (1990) Anal Chem 62(19): 2145-2148. PubMed | CrossRef |Others

2. Aulakh, J.S., Malik, A.K., Kaur, V., et al. A review on solid phase micro extraction high performance liquid chromatography (SPMEHPLC) analysis of pesticides. (2005) Crit Rev Anal Chem 35: 71-85. PubMed | CrossRef $\mid$ Others

3. Barcelo, D., Hennion, M.-C. On-line sample handling strategies for the trace-level determination of pesticides and their degradation products in environmental waters. (1995) Anal Chim Acta 318(1): 1-41.

PubMed | CrossRef $\mid$ Others

4. Belardi, R.P. Pawliszyn, J. Application of chemically modified fused silica fibers in the extraction of organics from water matrix samples and their rapid transfer to capillary columns. (1989) Water Qaulity Res J Can 24(1): 179-191.

PubMed | CrossRef| Others

5. Beltran, J., Lopez, F.J., Hernandez, F. Solid-phase micro-extraction in pesticide residue analysis. (2000) J Chromatogr A 885(1-2): 389-404.

PubMed | CrossRef | Others

6. Beltran, J., Peruga, A., Pitarch, E., et al. Application of solid-phase microextraction for the determination of pyrethroid residues in vegetable samples by GC-MS. (2003) Anal Bioanal Chem 376(4): 502-511.

PubMed |CrossRef | Others

7. Bhanti, M., Taneja, A. Monitoring of organochlorine pesticide residues in summer and winter vegetables from Agra, India-a case study. (2005) Environ Monit Assess 110(1-3): 341-346.

PubMed | CrossRef |Others

8. Bianchi, F., Careri, M., Musci, M. Fish and food safety: Determination of formaldehyde in 12 fish species by SPME extraction and GC-MS analysis. (2007) Food Chem 100(3): 1049-1053.

PubMed | CrossRef | Others

9. Dikshit, T.S.S., Raizada, R.B., Kumar, S.N., et al. Residues of DDT and $\mathrm{HCH}$ in major source of drinking water in Bhopal, India. (1990) Bull Environ Contam Toxicol 45(3): 389-393.

PubMed | CrossRef | Others

10. Frank, R., Braun, H.E., Ripley, B.D. Residue of insecticide, fungicides and herbicide in fruits produced in Ontario, Canada. (1987) Bull Environ Contam Toxicol 39(2): 272-279. PubMed | CrossRef | Others

11. Holt, R. Mechanisms Effecting analysis of volatile flavour components by solid-phase microextraction and gas chromatography. (2001) J Chromatogr A 937(1-2): 107-114. PubMed | CrossRef | Others

12. Kataoka, H., Lord, H.L., Pawliszyn, J. Applications of solid-phase microextraction in food analysis. (2000) J Chromatogr A 880(1-2): 35-62.

PubMed | CrossRef | Others

13. Kumari, B., Gulati, R., Kathpal, T.S. Monitoring of pesticidal contamination in honey. (2003a) The Korean J Apicult 18(2): 155-160.

PubMed | CrossRef $\mid$ Others

14. Kumari, B., Kathpal, T.S. Monitoring of pesticide residues in vegetarian diet. (2008) Environ Monit Assess 151(1-4): 19-26. PubMed | CrossRef | Others

15. Kumari, B., Kumar, R., Madan, V.K., et al. Magnitude of pesticidal contamination in winter vegetables from Hisar, Haryana. (2003b) Environ Monit Assess 87(3): 311-318. PubMed | CrossRef $\mid$ Others

16. Kumari, B., Madan, V.K., Kathpal, T.S. Monitoring of pesticide residues in fruits. (2006) Environ Monitor Assess 123(1-3): 407-441. 
PubMed $\mid$ CrossRef $\mid$ Others

17. Kumari, B., Madan, V.K., Kumar, R., et al. Monitoring of seasonal vegetables for pesticide residues. (2002) Environ Monit Assess 74(3): 263-270.

PubMed | CrossRef | Others

18. Kumari, B., Madan, V.K., Singh, J., et al. Monitoring of pesticidal contamination of farmgate vegetables from Hisar. (2004) Environ Monit Assess 90(1-3): 65-77.

PubMed | CrossRef $\mid$ Others

19. Kumari, B., Singh, J., Singh, S., et al. Monitoring of butter and ghee (clarified butter fat) for pesticidal contamination from cotton belt of Haryana, India. (2005) Environ Monitor Assess 105(1-3): 111-120.

PubMed | CrossRef $\mid$ Others

20. Lamprodon, D.A., Albanis, T.A. Headspace solid-phase microextraction applied to the analysis of organophosphorus insecticides in strawberry and cherry juices. (2002) J Agric Food Chem 50(12): 3359-3365.

PubMed | CrossRef | Others

21. Matich, A.J., Rowan, D.D., Banks, N.H. Solid-phase microextraction for quantitative headspace sampling of apple volatiles. (1996) Anal Chem 68(23): 4114-4118.

PubMed |CrossRef | Others

22. Mestres, M., Busto, O. Headspace solid-phase microextraction analysis of volative sulphides and disulphides in wine aroma. (1998) J Chromatogr A 808(1-2): 211-218. PubMed |CrossRef |Others

23. Pagliuca, G., Gazzotti, T., Zironi, E., et al. Residue analysis of organophosphorus pesticides in animal matrices by dual column capillary gas chromatography with nitrogen-phosphorus detection. (2005) J Chromatogr A 1071(1-2): 67-70. PubMed | CrossRef | Others

24. Quintero, A., Caseiies, M.J., Ettiene, G., et al. Monitoring of organphosphorus pesticide residues in vegetables of agricultural area in Venezuela. (2008) Bull Environ Contam Toxicol 81(4): 393-396. PubMed |CrossRef | Others

25. Shahi, D.K., Nisha, K., Sharma, A. Monitoring of pesticide residues in market vegetable at Ranchi, Jharkhand (India). (2005) J Environ Sci Eng 47(4): 322-325.

PubMed | CrossRef | Others

26. Song, J., Gardner, B.D., Holland, J.F., et al. Rapid analysis of volatile flavour compounds in apple fruit using SPME and GC/Time-of-Flight Mass Spectrometry. (1997) J Agricult Food Chem 45: 1801-1807. PubMed | CrossRef | Others

27. Song, J., Fan, L., Beaudry, R.M. Application of solid-phase microextraction and Gas Chromatography/Time-of-Flight Mass Spectrometry for rapid analysis of Flavour volatiles in tomato and strawberry fruits. (1998) J Agricult Food Chem 46: 3721-3726. PubMed $\mid$ CrossRef $\mid$ Others

28. Wang, L., Yongchao, L., Xin, J. Analysis of eight organphosphorus pesticide residues in fresh vegetables retailed in agricultural product market of Nanjing, China. (2008) Bull Environ Contam Toxicol 81(4): 377-382.

PubMed | CrossRef | Others
Submit your manuscript to Ommega Publishers and we will help you at every step:

- We accept pre-submission inquiries

- Our selector tool helps you to find the most relevant journal

- We provide round the clock customer support

- Convenient online submission

- Thorough peer review

- Inclusion in all major indexing services

- Maximum visibility for your research

Submit your manuscript at

https://www.ommegaonline.org/submit-manuscript 